\title{
UPAYA MENINGKATKAN PRESTASI BELAJAR MATEMATIKA MELALUI MODEL PEMBELAJARAN KOOPERATIF JIGSAW
}

\author{
Iput Saputro, Afif Afghohani, Isna Farahsanti \\ Universitas Veteran Bangun Nusantara Sukoharjo, Jalan Letjend Humardani No.1 \\ Sukoharjo, Jawa Tengah \\ iputsapotro01@gmail.com
}

\begin{abstract}
Abstrak
Tujuan penelitian ini adalah untuk meningkatkan prestasi belajar matematika melalui model pembelajaran kooperatif Jigsaw pada siswa kelas VIII A MTs Al Jauhar Semin Kabupaten Gunungkidul tahun pelajaran 2018/2019.Penelitian ini merupakan penelitian tindakan kelas yang terdiri atas dua siklus, dalam setiap siklus terdapat empat langkah yaitu perencanaan (planning), tindakan (acting), pengamatan (observating) dan refleksi (reflecting). Populasi dari penelitian ini adalah seluruh siswa Kelas VIII A MTs Al Jauhar sejumlah 24 siswa. Teknik pengumpulan data yaitu dengan metode observasi dan tes.Hasil penelitian menunjukkan meningkatnya nilai ratarata pada kondisi awal 62,1 menjadi 73,75 pada siklus I kemudian meningkat menjadi 85 pada siklus II. Dilihat dari siswa yang tuntas KKM, pada kondisi awal 3 siswa atau 12,5\% meningkat menjadi 14 siswa atau 58,33\% pada siklus I dan 23 siswa atau 95,83\% pada siklus II. Dari hasil penelitian tersebut nampak bahwa terjadi proses peningkatan prestasi belajar siswa dari sebelum tindakan, setelah tindakan siklus I maupun siklus II dalam pembelajaran dengan menggunakan model pembelajaran Jigsaw.Berdasarkan pada hasil penelitian tindakan kelas ini, dapat disimpulkan bahwa terjadi peningkatan Prestasi belajar matematika materi lingkaran setelah menggunakan model pembelajaran Jigsaw siswa kelas VIII A MTs Al Jauhar Semester II Tahun Pelajaran 2018/2019.
\end{abstract}

Kata Kunci : penelitian tindakan kelas, prestasi belajar matematika, Jigsaw

\begin{abstract}
The purpose of this study was to improve mathematics learning achievement through the Jigsaw cooperative learning model for students of class VIII A MTs Al Jauhar Semin Gunungkidul in academic year 2018/2019. This research was a classroom action research consisting of two cycles, in each cycle there were four steps, namely planning (planning), action (acting), observation (observating) and reflection (reflecting). The population of this study were all Class VIII A MTs Al Jauhar students. That was 24 students. The data collection techniques were conducted by observation and test methods.The results showed an increase in the average value in the initial conditions 62.1 to 73.75 in the first cycle and then increased to 85 in the second cycle. Viewed from students who complete KKM, in the initial condition 3 students or $12.5 \%$ increased to 14 students or $58.33 \%$ in the first cycle and 23 students or $95.83 \%$ in the second cycle. From the results of the study it proved that there was a process of increasing student learning achievement from before the action, after the action of cycle I and cycle II in learning using the Jigsaw learning model.Based on the results of this class action research, it concluded that there was an increase in learning achievement in mathematics circle material after using the Jigsaw learning model at students grade VIII A of MTs Al Jauhar in second semester at academic year 2018/2019.
\end{abstract}

Keywords: classroom action research, mathematics learning achievement, Jigsaw 


\section{Pendahuluan}

Dalam dunia pendidikan sebuah kegiatan pembelajaran sangat berpengaruh dalam pencapaian kompetensi siswa. Agar tujuan pembelajaran yang ditetapkan dapat tercapai, maka diperlukan desain pembelajaran yang dapat memotivasi siswa dalam belajar.

Matematika dalam proses pembelajarannya terkesan dipandang menyulitkan, menakutkan, bahkan tidak menyenangkan. Guru dalam proses pembelajaran matematika biasanya menggunakan metode konvensional atau sering dikenal dengan metode ceramah. Inilah yang menyebabkan peserta didik minim peran dan kurang tertarik dalam proses pembelajaran. Seperti yang terjadi di kelas VIII A MTs Al Jauhar Semin Gunungkidul ada 9 siswa dari 24 siswa $(37,5 \%)$ yang tidak memperhatikan guru yang sedang menjelaskan di depan kelas. Mereka cenderung berbicara sendiri, mengobrol dengan teman semejanya. Ada pula yang terlihat mengantuk dan tidak fokus pada pembelajaran yang sedang berlangsung. Terlihat antusias siswa dalam proses belajar mengajar rendah yaitu $62,5 \%$. Hal ini sangat berpengaruh pada prestasi siswa, dan itu terlihat dari hasil belajar siswa pada ulangan tengah semester genap hanya ada 3 siswa dari siswa 24 siswa (12,5\%) yang mendapat nilai diatas KKM yaitu 75 dan rata-rata nilai seluruh siswa masih rendah yaitu 62,1.

Berdasarkan uraian di atas dapat di rumuskan satu rumusan masalah sebagai berikut : Apakah melalui model pembelajaran kooperatif Jigsaw dapat meningkatkan prestasi belajar Matematika siswa kelas VIII A MTs Al Jauhar Semin kabupaten Gunungkidul tahun pelajaran 2018/2019?

Model pembelajaran yang tepat sangat berpengaruh atas keberhasilan proses belajar mengajar dikelas. Sebagai pendidik, perlu mencoba menerapkan berbagai model dan metode yang sesuai dengan tuntutan materi pembelajaran, termasuk dalam penerapan model pembelajaran kooperatif dengan metode belajar kelompok.

Penelitian yang dilakukan oleh Ummi Rosyidah pada tahun 2016 dengan judul Pengaruh Model Pembelajaran Kooperatif Tipe Jigsaw Terhadap Hasil Belajar Matematika Siswa Kelas VIII SMP Negeri 6 Metro. Hasilnya adalah, bahwa rata-rata hasil belajar siswa yang diajarkan dengan menggunakan model pembelajaran kooperatif tipe Jigsaw lebih tinggi dibanding dengan menggunakan model pembelajaran konvensional (metode ceramah). Pembelajaran Jigsaw merupakan model pembelajaran yang menarik untuk digunakan jika materi yang akan dipelajari dapat dibagi menjadi beberapa bagian dan materi tersebut tidak mengharuskan urutan penyampaian. 
Menurut Hamdani (2011: 92) model pembelajaran Jigsaw yaitu guru membagi satuan informasi yang besar menjadi komponen-komponen kecil. Selanjutnya, guru membagi siswa ke dalam kelompok belajar kooperatif, yang terdiri atas empat orang siswa sehingga setiap anggota bertanggung jawab terhadap penguasaan setiap komponen atau subtopik yang ditugaskan guru dengan sebaik-baiknya. Siswa dari tiap-tiap kelompok yang bertanggung jawab terhadap subtopik yang sama membentuk kelompok lagi yang terdiri atas dua atau tiga orang.

Kelebihan model pembelajaran ini antara lain, model pembelajaran ini dapat melibatkan seluruh siswa dalam belajar dan sekaligus mengajarkan kepada orang lain, materi pelajaran dapat dibagi menjadi beberapa sub materi, ada pembagian tugas dalam setiap kelompok, mengajarkan sikap kepemimpinan kepada siswa, masing-masing siswa mempunyai tanggung jawab yang sama besarnya, siswa dapat menguasai hampir semua materi pelajaran karena antar siswa saling mengajari. Metode pembelajaran Jigsaw ini dimungkinkan dapat meningkatkan prestasi belajar siswa.

\section{Metode Penelitian}

Penelitian ini merupakan Penelitian Tindakan Kelas (PTK) yaitu penelitian yang bertema kelas yang dilaksanakan oleh guru untuk memecahkan masalah yang berkaitan dengan pembelajaran yang dihadapi di kelas dan mencoba hal-hal baru dalam pembelajaran guna meningkatkan mutu dan hasil belajar.

Penelitian tindakan kelas merupakan kegiatan pemecahan masalah dengan tahap sebagai berikut: perencanaan, pelaksanaan tindakan, observasi, refleksi.

Keempat tahap dalam penelitian tersebut merupakan satu siklus, yaitu satu putaran tindakan yang beruntun atau berurutan, dari tahap penyusunan rancangan pembelajaran sampai dengan refleksi, yang tidak lain yaitu evaluasi.

Model pembelajaran adalah suatu pola pembelajaran yang tergambar dari awal hingga akhir kegiatan pembelajaran yang tersusun secara sistematis dan digunakan sebagai pedoman untuk merencanakan kegiatan pembelajaran untuk mencapai tujuan pembelajaran yang telah ditetapkan.

Dalam penelitian ini, model pembelajaran yang digunakan adalah model pembelajaran kooperatif Jigsaw, karena selama ini masih menggunakan model pembelajaran konvensional dan model pembelajaran Jigsaw belum pernah diterapkan dalam kegiatan belajar mengajar di kelas.

Sumber data yang digunakan dalam penelitian ini adalah guru pengampu mata pelajaran Matematika dan siswa kelas VIII A MTs Al Jauhar Tahun Pelajaran 2018/2019. 


\section{Hasil dan Pembahasan}

Penelitian ini terdiri dari pra siklus, sikli]us I, dan siklus II. Penelitian pra siklus dilakukan dengan mengambil nilai hasil belajar siswa kelas VIII A MTs Al Jauhar. Sebelum melakukan tindakan pembelajaran dengan model pembelajaran kooperatif tipe Jigsaw, terlebih dahulu menggunakan pembelajaran konvensional, dengan hasil pra siklus sebagai berikut.

Tabel 1. Ketuntasan Belajar Siswa Kondisi Awal

\begin{tabular}{cccc}
\hline No. & Ketuntasan & Jumlah & $\%$ \\
\hline 1. & Tuntas & 3 & 12,5 \\
2. & Belum Tuntas & 21 & 87,5 \\
& Jumlah & 24 & 100 \\
\hline
\end{tabular}

Dilihat dari ketuntasan belajar yang masih rendah dengan rata rata nilai 62,1 dengan nilai terendah 50 dan nilai tertinggi 80 , maka sangat perlu dilakukan tindakan kelas untuk meningkatkan prestasi belajar siswa

Setelah observasi tersebut selesai dilaksanakan, peneliti dapat mengambil kesimpulan berdasarkan informasi yang telah didapatkan. Kesimpulan tersebut semakin menguatkan peneliti untuk dapat melaksanakan penelitian tindakan kelas dengan strategi pembelajaran Jigsaw.

Tabel 2. Ketuntasan Belajar Siswa Siklus I

\begin{tabular}{cccc}
\hline No. & Ketuntasan & Jumlah & $\%$ \\
\hline 1. & Tuntas & 14 & 58,33 \\
2. & Belum Tuntas & 10 & 41,67 \\
& Jumlah & 24 & 100 \\
\hline
\end{tabular}

Pada siklus I nilai rata-rata 73,75 dengan nilai terendah 60 dan nilai tertinggi 90, setelah dilakukan siklus I sudah ada peningkatan. Melihat kondisi tersebut indikator kinerja yang ditetapkan yaitu rata-rata kelas $\geq 75$ belum tercapai, dan indikator jumlah siswa yang tuntas sebesar $70 \%$ juga belum terpenuhi sehingga perlu diadakan perbaikan tindakan yang diadakan pada siklus selanjutnya, yaitu siklus II.

Tabel 3. Ketuntasan Belajar Siswa Siklus II

\begin{tabular}{cccc}
\hline No. & Ketuntasan & Jumlah & $\%$ \\
\hline 1. & Tuntas & 23 & 95,83 \\
2. & Belum Tuntas & 1 & 4,17 \\
& Jumlah & 24 & 100 \\
\hline
\end{tabular}


Pada siklus II, dilihat dari rata-rata kelas 85 demgan nilai tertinggi 100 dan nilai terendah secara klasikal sudah di atas nilai Kriteria Ketuntasan Minimal untuk mata pelajaran matematika pada Madrasah Tsanawiyah Al Jauhar yaitu 75. Melihat kondisi tersebut berarti sebagian besar peserta didik sudah ada peningkatan prestasi belajarnya, bahkan ada beberapa siswa yang memperoleh nilai 100 .

Berdasarkan hasil penelitian yang telah diuraikan diatas dapat disimpulkan bahwa model pembelajaran kooperatif tipe Jigsaw dapat meningkatkan prestasi belajar siswa kelas VIII A MTs Al Jauhar.

Dalam proses pembelajaran di kelas suatu model pembelajaran sangat berpengaruh terhadap prestasi belajar siswa. Penelitian yang dilakukan oleh Annisa Prima Exacta, Isna Farahsanti pada tahun 2016 dengan judul Implementasi Model Pembelajaran Numbered Heads Together (NHT) untuk Meningkatkan Pemahaman dan Minat Belajar Mahasiswa. Hasilnya adalah, Implementasi model pembelajaran NHT dapat meningkatkan minat belajar dan pemahaman mahasiswa.

Penelitian yang dilakukan oleh Isna Farahsanti, Annisa Prima Exacta pada tahun 2016 dengan judul Pendekatan Pembelajaran Metakognitif dengan Media Flash Swishmax pada Pembelajaran Matematika SMP. Hasilnya adalah, Pendekatan metakognitif dengan media Flash Swishmax memberikan prestasi belajar matematika yang lebih baik daripada pembelajaran konvensional.

Beberapa contoh penelitian diatas menununjukkan bahwa model pembelajaran sangat berpengaruh terhadap prestasi belajar siswa, tetapi pada kenyataannya masih banyak proses pembelajaran yang menggunakan model pembelajaran konvensional (ceramah).

\section{Simpulan dan Saran}

Berdasarkan hasil penelitian tindakan kelas yang telah dilaksanakan dapat disimpulkan bahwa melalui model pembelajaran kooperatif Jigsaw dapat meningkatkan prestasi belajar matematika pada siswa kelas VIII A MTs Al Jauhar Semin Gunungkidul tahun pelajaran $2018 / 2019$.

\section{Referensi}

Abidin, N. Z. 2017. Meningkatkan Hasil Belajar Matematika Melalui Model Pembelajaran Kooperatif Tipe Jigsaw pada Siswa SMP. Journal of Educational Science and Technology, Vol. 38, No. 31. (diakses 07 Mei 2019) https://creativecommons.org//licenses/by-nc/4.0/

Arikunto, S. 2010. Prosedur Penelitian. Jakarta: PT Rineka Cipta 
Asmadi, A. 2011. Pengaruh Metode Belajar Team Assited Individualization Terhadap Prestasi Belajar Statistika Pada Mahasiswa Psikologi. Jurnal Psikologi: Vol 38, No. 1. (diakses tanggal 20 Maret 2019) [https://jurnal.ugm.ac.id/jpsi/article/view/7667

Astuti, F. N. 2018. Keefektifan Model Pembelajaran Bamboo Dancing dan Jigsaw Ditinjau Dari Hsail Belajar Matematika Siswa Kelas 4 SD. Jurnal Teori dan Aplikasi

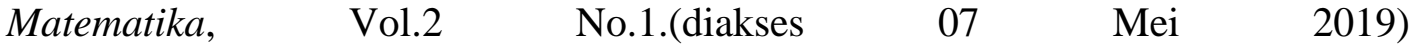
https://scholar.google.co.id/scholar?hl=id\&as_sdt=0\%2C5\&q=model+pembelajara $\mathrm{n}+$ jigsaw+2018\&oq=\#d=gs_qabs\&u=\%23p\%3DEocuPIWQWNQJ

Berlin, K. d. 2016. Ragam Pengembangan Model Pembelajaran. Kata Pena.

Exacta, A. p. 2016. Implementasi Model Pembelajaran Numbered Heads Together (NHT) Untuk Meningkatkan Pemahaman dan Minat Belajar Mahasiswa. Jurnal Pendidikan dan Pembelajaran Matematika (JP2M), Vol. 2 No. 2.(diakses 01 Agustus 2019) https://scholar.google.co.id/scholar?hl=id\&as_sdt=0\%2C5\&q=jurnal+implement asi + univet $\& b t n G=\# d=g s \_q a b s \& u=\% 23 p \% 3 D G o l T G t 16 A M 8 J$

Farahsanti, I. 2016. Pendekatan Pembelajaran Metakognitif dengan Media Flash Swishmax pada Pembelajaran Matematika SMP. Jurnal Pendidikan dan Pembelajaran Matematika (JP2M), Vol. 2 No. 2.(diakses 01 Agustus 2019) https://scholar.google.co.id/scholar?hl=id\&as_sdt=0\%2C5\&q=jurnal+matematika+ univet+pendekatan+pembelajaran+metakognitif+dengan+media+flash+swishmax\& $\mathrm{btnG}=\# \mathrm{~d}=\mathrm{gs} \_\mathrm{qabs} \& \mathrm{u}=\% 23 \mathrm{p} \% 3 \mathrm{DHoU} 7 \mathrm{khdiD} 0 \mathrm{MJ}$

Heruman. 2013. Model Pembelajaran Matematika Di Sekolah Dasar. Bandung: PT Remaja Rosdakarya.

Mawarni, H. J. 2016. Upaya Meningkatkan Prestasi dan Minat Belajar Matematika melalui Model Pembelajaran Kooperatif Jigsaw Pada Siswa Kelas VII G SMP N 2 Tawangsari Kabupaten Sukoharjo Tahun Pelajaran 2015/2016. Skripsi Universitas Veteran Bangun Nusantara Sukoharjo (tidak terbit)

Ninda Beny Asfuri, R. Y. 2019. Penerapan Model Pembelajaran Kooperatif Tipe Jigsaw Untuk Meningkatkan Aktivitas Dan Hasil Belajar Matematika Materi Simetri Lipat Bangun Datar Pada Peserta Didik Kelas Iii Sd Negeri Baturan Semester 2 Tahun 2018. Jurnal Ilmiah Mitra Swara Ganesha, Vol.6 No.1. (diakses 07 Mei 2019) http://ejournal.utp.ac.id/index.php/JMSG/article/view/792/520520644

Rosyidah, U. 2016. Pengaruh Model Pembelajaran Kooperatif Tipe Jigsaw Terhadap Hasil Belajar Matematika Siswa Kelas VIIi SMP Negeri 6 Metro. Jurnal SAP, Vol. 1 No. 2. (diakses

$07 \quad$ Mei https://www.google.com/url?sa=t\&source=web\&rct=j\&url=https://journal.lppmuni ndra.ac.id/index.php/SAP/article/download/1018/999\&ved=2ahUKEwjIo342YjiAhUD73MBHcC1BQAQFjAAegQIBRAB\&usg=AOvVaw0uvSX6p8fyujt JlMFTmHz2

Sugiyono. 2010. Statistika Untuk Penelitian. Bandung: Alfabeta.

Wahyudi. 2018. Upaya Meningkatkan Prestasi Belajar Matematika Siswa Kelas VII FD.1 Madrasah Tsanawiyah Negeri Sukoharjo Tahun Pelajaran 2017/2018 Dengan 
Menerapkan Model Pembelajaran Discovery Learning. Skripsi Universitas Veteran Bangun Nusantara Sukoharjo (tidak terbit)

Zain, S. B. 2013. Strategi Belajar Mengajar. Jakarta: Rineka Cipta. 